\title{
LONG-RUN EARNINGS VOLATILITY AND HEALTH INSURANCE COVERAGE: EVIDENCE FROM THE SIPP GOLD STANDARD FILE
}

by

\author{
Matthew S. Rutledge * \\ Boston College
}

CES 11-35

October, 2011

The research program of the Center for Economic Studies (CES) produces a wide range of economic analyses to improve the statistical programs of the U.S. Census Bureau. Many of these analyses take the form of CES research papers. The papers have not undergone the review accorded Census Bureau publications and no endorsement should be inferred. Any opinions and conclusions expressed herein are those of the author(s) and do not necessarily represent the views of the U.S. Census Bureau. All results have been reviewed to ensure that no confidential information is disclosed. Republication in whole or part must be cleared with the authors.

To obtain information about the series, see www.census.gov/ces or contact Cheryl Grim, Editor, Discussion Papers, U.S. Census Bureau, Center for Economic Studies 2K130B, 4600 Silver Hill Road, Washington, DC 20233, CES.Papers.List@census.gov. 


\begin{abstract}
Despite the notable increase in earnings volatility and the attention paid to the growing ranks of the uninsured, the relationship between career earnings and short- and medium run health insurance status has been ignored due to a lack of data. I use a new dataset, the SIPP Gold Standard File, that merges health insurance status and demographics from the Survey of Income and Program Participation with career earnings records from the Social Security Administration (SSA) and the Internal Revenue Service (IRS) to examine the relationship between long-run family earnings volatility and health insurance coverage. I find that more volatile career earnings are associated with an increased probability of experiencing an uninsured episode, with larger effects for men, young workers, and the unmarried. These findings are consistent with the "scarring" literature, and suggest the importance of safety-net measures for job losses and health insurance coverage.

* This project was supported by the National Poverty Center (NPC) using funds received from the U.S. Census Bureau, Housing and Household Economics Statistics Division, through contract number 50YABC266059/TO002. Any opinions and conclusions expressed herein are those of the author and do not necessarily represent the views of the U.S. Census Bureau, the NPC, the Social Security Retirement Research Consortium, or Boston College. All results have been reviewed to ensure that no confidential information is disclosed. The author thanks Luke Shaefer, Steve Haider, Peter Gottschalk, Martha Stinson, Gary Benedetto, Graton Gathright, Jim Davis, Clint Carter, Shawn Pelak, Sheldon Danziger, Zoë McLaren, Brian Rowe, and George Lausch for their helpful comments and assistance in accessing and using the data. Dan Leeds provided excellent research assistance.
\end{abstract}




\section{Introduction}

Over the last few decades, the volatility of earnings has followed a general, if inconsistent, upward trend (Shin and Solon, 2008), contributing substantially to the rise in earnings inequality (Haider, 2001). Meanwhile, the growing ranks of the uninsured have received a great deal of attention, both from researchers and policymakers. Despite the obvious link between labor income and health insurance, as the vast majority of nonelderly Americans receive health coverage through an employer (DeNavas-Walt, Proctor, and Smith, 2009), the relationship between increasing earnings instability and health insurance coverage has been largely unexplored.

Until recently, there was no data source that provided long-term earnings histories and insurance status. For example, the most prominent long-run longitudinal dataset, the Panel Study of Income Dynamics (PSID), only began asking about insurance status in 1997. A recent joint effort led by the U.S. Census Bureau and the Social Security Administration (SSA) has resulted in a new data source that links health insurance information, among other variables, from the Survey of Income and Program Participation (SIPP) to administrative data on earnings from the SSA records.

In this paper, I use this linked data, the SIPP Gold Standard File, to estimate the relationship between long-run earnings volatility and short- and medium-run health insurance coverage. I use a novel measure of earnings volatility that takes into account the natural growth of real earnings as an individual ages. I test the hypothesis that, for two individuals who have the same fitted long-run trend in family earnings, the one whose earnings deviate more from that trend is more likely to be uninsured, no matter 
when the researcher observes him or her. To my knowledge, this is the first paper to examine the relationship between career earnings, in either levels or volatility, and health insurance coverage.

I find that there is a large positive and statistically significant relationship between long-run family earnings volatility and the probability that someone ever experiences a period without health insurance coverage. This effect is strongest for men, workers under age 30, and the unmarried, who are exposed to greater downside earnings risk and job insecurity. I also find, on the other hand, that earnings volatility has a weaker influence on the time spent uninsured for these groups, consistent with short, frequent uninsured spells, and that those workers who have more volatile earnings are not more likely to be continuously uninsured. In short, inconsistency in one’s career earnings profile translates into inconsistent health care coverage.

Though the exact cause of earnings volatility is still subject to debate, a likely substantial contributor is the effect of job displacement (Stevens, 2001). Numerous researchers have found that job loss may have a "scarring” effect (Ellwood, 1982), making future losses more likely (Stevens, 1997), decreasing the quality of subsequent employer-employee matches (Fallick, 1996), and reducing earnings over the long run (Ruhm, 1991, Jacobsen, LaLonde, and Sullivan, 1993). If one job loss makes future displacement more likely, and leaves even re-employed workers with lower-quality jobs than other workers who were never displaced, then we should also observe that previously displaced workers are less likely to be covered by health insurance at any point-in-time. The "scarring" of job displacement may also lead to undesirable health insurance dynamics: insured workers who have a volatile earnings history may be more 
likely to lose insurance, and less likely to gain insurance once it is lost. These dynamics suggest an increased need for safety-net insurance coverage in the event of job loss, and strengthen the motivation for measures that reduce the negative impacts of job displacement, such as job training, continuing education, and unemployment insurance.

\section{Related Literature}

The literature suggests that earnings volatility has trended upward over the last few decades. Gottschalk and Moffitt $(1994,1995)$ decompose earnings variance into its permanent and transitory elements, and find that transitory earnings variance increased between the 1970s and 1980s. In a recent update (2008), they find that volatility remained at this higher level through 2004, though it did not increase further. Haider (2001) also finds that earnings instability increased substantially in the 1970s, explaining about half of the growth in earnings inequality. Though Cameron and Tracy (1998) and Moffitt and Gottschalk (2002) find that earnings volatility declined in the late 1980s and early 1990s, and Dahl, DeLeire, and Schwabish (2008) suggest that volatility has leveled off since the mid-1980s, recent evidence suggests that volatility has risen again in the 2000s (Dynan, Elmendorf, and Sichel, 2007; Shin and Solon, 2008).

Stevens (2001) attributes much, but not all, of this growth in the transitory earnings variance to the persistence of earnings losses after job displacement. Numerous papers have found that job loss leads to less stable future employment and permanently lower wages. Ruhm (1991), Jacobsen, LaLonde, and Sullivan (1993), and Stevens (1997) find evidence that workers who lose a job may be "scarred" for years, even after 
re-employment, with lower wages, increased probability of future job losses, and permanently increased earnings volatility.

Job losses may also lead to the loss of health insurance, as employers are the source for about three-quarters of non-elderly insured Americans' coverage (DeNavasWalt, Proctor, and Smith, 2009). Gruber and Madrian (1997) find that job loss is frequently associated with insurance loss, and Czajka and Olsen (2000) find a similar effect of parental job loss on children’s insurance coverage.

While the research on the permanent effects of job displacement on direct labor market outcomes is rich, very little is known about the long-run effects of job losses and earnings volatility on health insurance. To my knowledge, the only previous study to examine this question is Simon and Schroder (2006). Using the 1996 and 2001 panels of the SIPP, they find that previously involuntarily displaced workers are significantly less likely to have insurance through their next job than workers who had not been displaced, though the displaced workers eventually catch up to the other workers after just more than a year.

This study is the first to examine the relationship between point-in-time health insurance status and either the level or the volatility of long-run earnings. The availability of the SIPP Gold Standard File makes this analysis possible; while previous studies use the PSID to examine earnings volatility, questions about insurance coverage are only available relatively recently, earnings totals are self-reported, and the sample size is much smaller. 


\section{Conceptual Framework}

It is well-established that individuals who have high-paying jobs are likely to have stable health insurance coverage (see, among many others, Kuttner and Rutledge, 2007).

Because the employer is the dominant source of coverage in the United States, contemporaneous earnings volatility, especially when it is caused by a job loss, will be strongly associated with being uninsured point-in-time (Gruber and Madrian, 1997), or ever experiencing a gap in coverage (Short and Graefe, 2003).

This paper examines a slightly different question: whether, all else (including the earnings level) equal, an individual who has a more volatile family earnings history is more likely to be uninsured at any particular time. My hypothesis is that, controlling for the long-run level of earnings, someone with a history of more variable earnings is also more likely to have gaps in his or her health insurance coverage.

The association between volatile earnings history and volatile insurance status may arise for any number of reasons. First, unstable earnings may be a signal of the worker's unobserved ability. It is important to note that earnings volatility, at least across years, is likely to arise mostly because of downside, not upside, risk. Unlike total income, which may have significant upside due to investment windfalls, property sales, inheritance, or lottery winnings, substantial year-to-year positive shocks to labor market income (including both non-deferred and deferred earnings) are relatively rare. ${ }^{3}$

\footnotetext{
${ }^{3}$ A potential exception is workers whose bonuses make up a large portion of their annual earnings. It would be worthwhile to exclude workers in certain industries like finance, but in the Gold Standard File, industry is only known within broad categories (for example, finance is combined with insurance, real estate, public administration, the military, and most other services). Industry is also observed only during the time they are sampled by the SIPP, and workers may spend some unspecified amount of time in both finance and other professions less reliant on bonuses.
} 
Substantial negative shocks, however, are quite common, due to job losses or cuts in hours. Moreover, earnings are much more likely to change, up or down, with job and employer transitions, ${ }^{4}$ which also leaves a worker vulnerable to gaps in insurance coverage. ${ }^{5}$ Volatile earnings, therefore, suggest a tenuous connection to the labor market, through frequent and/or persistent periods of non-employment, seasonal or temporary work, or inconsistent hours within a position. A history of volatile earnings, then, could be evidence that the individual is of low ability, and therefore has trouble obtaining, and maintaining, high-quality jobs that are likely to offer stable health insurance coverage, even if earnings observed in the short-run, as it would be in many longitudinal studies, are stable. Low-ability individuals or those with frequent transitions may also be less likely to seek coverage if it is not offered by an employer, as the individual insurance market has high transaction costs.

Alternatively, there is some evidence in the literature that labor market shocks are persistent and may cause "scarring," making individuals who suffer layoffs or cuts in hours more likely to repeat these negative results, while being unable to restore their

\footnotetext{
${ }^{4}$ Bils (1985), Shin (1994), and Devereux and Hart (2006) find that wages of workers who remain in the same job are much more acylical than job movers, both across and within employers.

${ }^{5}$ Gruber and Madrian (1997) find that job loss decreases the probability of private coverage by 20 percentage points. They add that mandated continued coverage, at the state level, dramatically increases the probability of retaining coverage during a job transition; this continued coverage is now mandated at the national level, after the passage of the Health Insurance Portability and Accountability Act in 1996, so coverage should be easier to maintain during job-to-job transitions (though not necessarily with longer unemployed spells).
} 
previous earnings level. ${ }^{6}$ This suggests that previous earnings volatility reduces current earnings, which may result in periods without health insurance coverage.

Finally, an individual who has volatile earnings may have low risk aversion. He or she may therefore have little demand for protection against financial risk, and is unwilling to pay, or sacrifice wages, for health insurance at its market rate. Also, an individual may feel that he or she does not need continuous coverage if he or she has been uninsured in the past without consequence.

As a result of some or all of these factors, I expect that individuals who have volatile earnings histories are more likely to lack health insurance coverage in any period in which we observe them. I also expect past earnings volatility to be associated with an increased chance of losing coverage if one is insured, and a decreased probability of gaining coverage if one is uninsured, though the current version of this paper does not explicitly test this prediction.

Differences between the genders in long-run stability in labor force participation are likely to affect this estimated relationship between earnings volatility and health insurance status. Men may leave the labor force, but for reasons for which I can account with the volatility measure. First, if men retire or pursue education, these actions generally occur at the beginning or end of careers, while my volatility measure focuses on mid-career gaps. Second, men may get discouraged by joblessness and stop searching, which would coincide with the years of decreased earnings that lead to more volatile earnings, exactly the effect I am trying to capture.

\footnotetext{
${ }^{6}$ Stevens (1997) finds that earnings remain below their peak level even six or more years after the initial job loss.
} 
Women, however, often have years of decreased or zero earnings mid-career due not to the lack of success in a career, but for child rearing or the care of an elderly relative. Goldin (2006) finds that though women's labor force participation at any one time has risen, just under half of mothers who graduated from a "selective" college in 1976 have left the labor force within the first 20 years of their careers. Most women will be able to retain health insurance coverage during this period, either through a spouse or by becoming eligible for Medicaid. Women will therefore appear to have more volatile earnings due to gaps in their earnings histories, but this will not necessarily be associated with gaps in health insurance coverage.

Regardless of gender, a married adult's own annual earnings and own employment relationship do not fully reflect the resources available to him or her in that year. Many Americans acquire health insurance coverage through a spouse's employer, purchase coverage on the private market using shared income, or are eligible for public coverage due to sufficiently low family income. For married individuals, then, earnings volatility should reflect the variability of resources available, not just at the individual level, but at the family level. A low-earnings year for one spouse due to a job separation, retirement, return to school, or career transition (but not a business start-up, as selfemployed workers are excluded) does not reflect their vulnerability, either to earnings losses or coverage lapses, if the other spouse maintains or even increases his or her earnings level in response. ${ }^{7}$

\footnotetext{
${ }^{7}$ Most of the work on earnings volatility cited above restricts their analysis to men. Dahl, Deleire, and Schwabish (2008) analyze earnings volatility only for separate individuals, but also consider household income (which would include non-labor income that may be subject to more upward risk than are
} 


\section{Data}

The SIPP Gold Standard dataset is the result of a collaboration of the Census Bureau, the SSA, the Internal Revenue Service (IRS), and the Congressional Budget Office (CBO) (Abowd, Stinson, and Benedetto, 2006). This dataset links information collected in the 1990-1993, 1996, 2001, and 2004 panels of the SIPP to earnings and benefits histories from SSA records.

The SIPP surveys households every four months during a two- to four-year period, about a variety of demographics, labor, welfare, and health topics in each intervening month. Each year between 1990 and 1993, and again in 1996, 2001, and 2004, SIPP began a new panel of households. The SIPP Gold Standard File contains a subset of variables available in the full SIPP data, including demographics, marital and fertility history, self-reported income and wealth, education, work status, industry and occupation, welfare receipt, and most importantly for this study, monthly health insurance coverage (any coverage, plus an indicator of employer-sponsored coverage). Survey questions featured in the Gold Standard subset are comparable across panels. ${ }^{8}$

earnings). Dynan, Elmendorf, and Sichel (2007) analyze households’ income and earnings, combining husband's and wife's earnings.

${ }^{8}$ For all SIPP variables, including health insurance status, I use the version that includes imputations for the public-use data. Unfortunately, the Gold Standard File does not carry over the imputation flags from the public-use SIPP; if it did, it would be possible to determine whether some observed spells without insurance are actually spurious products of the imputation process, as is likely. Ideally, I would eliminate anyone whose only uninsured months were imputed, and correct for their elimination in the SIPP weight adjustment. 
An individual is included in the SIPP Gold Standard dataset if he or she is age 15 or older and has a valid Social Security number on file (approximately 88 percent of the age-eligible sample). His or her earnings history is obtained from annual employer W-2 reporting to the IRS, which then goes into one's Detailed Earnings Record (DER) in the SSA's files. The Gold Standard dataset includes annual earnings variables from the DER dating to 1978 that includes deferred and non-FICA earnings, and no earnings variable is top-coded, unlike most other large-scale datasets. The Gold Standard File also includes (top-coded) earnings reports from the SSA's Summary Earnings Record (SER) dating back to $1951 .^{9}$ I retain only a single total earnings measure for each year of the matched SIPP respondent's career; following the recommendation from the Gold Standard codebook, I use the SER total for most individuals for most years, using the sum of all four DER categories (non-deferred and deferred earnings, both subject to and exempt from FICA tax) only if there are non-FICA earnings or the earnings have been topcoded. $^{10}$

To better reflect the family’s financial status and coverage availability, I combine annual earnings (in all available years) for couples who are married at the time that they

\footnotetext{
${ }^{9}$ Because earnings are top-coded at the Social Security maximum from 1951 to 1977 , but are not top-coded after 1978, earnings volatility may be either understated, as pre-1978 earnings fluctuations above the cap are unobserved, or overstated, because only any individual with post-1978 earnings above the cap will appear more volatile than they would otherwise. I include the results of regressions of insurance status on earnings volatility, where the latter measure is estimated only from earnings collected since 1978, as a robustness check, though results are qualitatively similar; see the last section.

${ }^{10}$ Census personnel suggest that some DER entries, particularly in 1978 and 1979, have typographical errors or are otherwise outliers in one's earnings history. Though I do not have access to the pre-cleaned DER record for each individual, I edit the earnings record before I estimate the earnings volatility measure. For example, I use the SER value where the DER total is exactly 10, 100, or 1000 times the SER entry (suggesting a misplaced decimal or extra zero). I also use the SER earnings value when the individual's earnings exceed \$1 million for the first and only time in one's history. These changes affect fewer than a couple dozen individuals.
} 
are interviewed by the SIPP, and report that the marriage is their first. For the nevermarried, the volatility measure accounts for only their own earnings profile. Results are similar whether I use combined earnings or each individual's earnings to calculate volatility, as shown in the robustness checks. In most specifications, I exclude those individuals who have ever been divorced, as there is no way to link their earnings profile to their ex-spouses' earnings.

I further restrict the sample to individuals who are between ages 18 and 64 throughout their time sampled by SIPP; for college graduates, I require that they are at least 22 years old throughout the SIPP sample. Without sufficient years of non-zero earnings, it would be difficult to measure volatility, so I also require that families (or individuals) have at least 10 different years of positive earnings in their history. These two restrictions limit the eligible birth cohorts differently by panel (Table 1); participants in the 1990 panel must have been born between 1927 and 1968 (for college graduates) or 1972 (no college degree), but 2004 panel members cannot be born after 1979, regardless of educational attainment, because of the requirement that they have 10 or more years of post-education work experience. I also eliminate any individual reporting selfemployment earnings at any point in the SSA data, as self-employment earnings are often underreported (Hurst, Li, and Pugsley, 2010).

Table 2 details how I refine the sample. The full Gold Standard File includes nearly 350,000 individuals. Of these, almost 92,000 are not linked to the Social Security earnings records due to a missing Social Security number. Another 25,000 have fewer than 10 years of positive earnings over their careers. Almost 87,000 of the remaining workers report self-employment earnings at some point during their careers. Finally, 
another 41,000 workers are ever divorced, are missing information on their final educational attainment, or do not have a valid adjusted SIPP weight. Thus, the final sample includes approximately 49,000 men and 55,000 women, or about 127,000 and 144,000 person-years, respectively.

\section{Methodology}

This paper's primary estimation model is a regression of short-run health insurance status on long-run earnings volatility, the long-run level of earnings, and other covariates.

The first challenge is the measurement of long-run earnings volatility. In the data, real earnings trend upward over one's career due to returns to experience and occupationand firm-specific capital, peaking in one’s 50s before reaching a plateau, or even declining, late in one's career. An individual's earnings variance is therefore a poor measure of volatility, as a worker who has a steep but consistent earnings profile (Figure 1, left panel) may grade out as more volatile than one who has a narrow but inconsistent profile (right panel). Moreover, for two otherwise-identical individuals who have different years of experience, the one who has more experience will look more volatile, as there is more of a difference in earnings between the first few and last few years of his career than for someone who has a shorter, more truncated profile.

An approach that better captures the consistency of year-to-year earnings, or lack thereof, while still taking into account the usual career earnings profile is to control for both predicted earnings throughout one's career and the deviation from that fitted profile. 
For two workers who have identical fitted earnings profiles, as shown in Figure 2, the one whose earnings deviate more from that trend line is clearly more volatile (right panel).

Individuals (or families) will be heterogeneous, both in their capacity to earn in any given year and in their ability to grow those earnings. Gender, marital status, and education may account for some of these differences. The typical male with a college degree will have a steeper earnings profile, starting from a higher initial salary, than an otherwise-equal male with only a high school diploma. Similarly, the age-earnings profile of a married woman likely will have a different shape than an equally-educated never-married woman. Also, birth cohort matters: a worker can earn more at age 30 if he or she reaches that age during a boom than if he or she reached it during a recession. ${ }^{11}$ Still, within these groups, the level and growth of earnings will vary greatly between individuals (or families); a social worker and a currency trader of the same age, marital status, and gender will both be college graduates, but will have very different earnings profiles, both in levels and in slope.

To account for this unobserved heterogeneity within cell $J$, I fit a cubic ageearnings profile to each matched respondent $i$ 's earnings history, ${ }^{12}$

$$
E A R N_{i J t}=\alpha_{0 J}+\alpha_{1 J} A g e_{i J t}+\alpha_{2 J} A g e_{i J t}^{2}+\alpha_{3 J} A g e_{i J t}^{3}+v_{i J t} .
$$

The error term $v$ consists of

\footnotetext{
${ }^{11}$ The literature on graduating during a recession (Kahn, 2010, for one) suggests that the effect of reaching a specific age - in this case, the age at which one normally earns a degree - in a specific year can have long-lasting effects on earnings ability.

${ }^{12}$ As a robustness check, I replace the $A V G R$ calculated by a cubic regression of age on real earnings, delineated above, with an $A V G R$ calculated from a quadratic regression of age on real earnings in each regression. All results are nearly identical in both magnitude and significance.
} 


$$
v_{i J t}=\lambda_{0 i J}+\lambda_{1 i J} A g e_{i J t}+v_{i j t}
$$

the sum of an observation-specific random intercept, an observation-specific slope parameter with respect to age, and a classical error term. The first term in (2) allows for unobserved heterogeneity on the level of earnings, while the middle term allows for unobserved heterogeneity on the growth rate of earnings. I estimate the model, using restricted maximum likelihood, separately for 314 birth cohort-gender-education-marital status cells for individuals, ${ }^{13}$ and 106 cells for married couples. ${ }^{14}$

The earnings volatility measure is the square root of the sum of the squared residuals from this regression, divided by the number of years $(T)$ the individual was included in the SSA earnings record (up to 47 years, if they were observed consistently from ages 18 to 64 between 1951 and 2006):

$$
A V G R_{i t}=\frac{\sqrt{\left(E A R N_{i t}-\overline{E A R N_{i t}}\right)^{2}}}{T}=\frac{1}{T} \sqrt{\left[\operatorname{EARN}_{i t}-\left(\hat{\alpha}_{0}+\hat{\alpha}_{1} A g e_{i t}+\hat{\alpha}_{2} A g e_{i t}^{2}+\hat{\alpha}_{3} A g e_{i t}^{3}\right)\right]^{2}} .
$$

In other words, $A V G R$, or the "average residual,” represents the average absolute value of the difference, in real (2000) dollars, between what the individual (or family) earned at a particular age and what their career earnings profile would have predicted they would

\footnotetext{
${ }^{13}$ For each birth cohort between 1927 and 1979, I estimate (1) for six different cells: men with less than a college degree, men with a college degree or more, women with less than a college degree who ever married, women with less than a college degree who never married, women with a college degree who ever married, and women with a college degree who never married. I do not separate men by marital status; in a regression where the dependent variable is the earnings volatility measure calculated for the sample as a whole, the interaction of indicator variables for male and ever married is not statistically significant, unlike the other interactions of gender, education, and marital status.

${ }^{14}$ In the estimates of earnings volatility for married couples, I include one observation per couple, and the cells are assigned by the birth cohort (1927-1979) and educational attainment (college degree or not) of the male. Each spouse is then assigned the joint earnings volatility measure, and each will be his or her own observation in the insurance regression.
} 
earn at that age. A more volatile earnings history results in a larger $A V G R$, as annual earnings more substantially deviate from the individual's fitted trend on average.

It is important to control for some measure of long-run earnings level, not just volatility; not only are higher earnings individuals less likely to be uninsured, but deviations that are small in percents are likely to add up to a much larger $A V G R$ the higher one's lifetime level of earnings. ${ }^{15}$ To control for the long-run level of earnings, ideally I would include the matched respondent's predicted value of real earnings, $\widehat{E A R N}_{i t}$, for each year of age as a regressor in the main regression, to control for the earnings level. These regressors are highly correlated, however, due to the serial correlation of earnings. Instead, I include the mean predicted real earnings level over four- or five-year periods: ages 18 to 21, 22 to 25, 26 to 30, and so on, up to ages 61 to $64 .^{16}$

The dependent variable is a measure of the lack of health insurance coverage, so the regression model is

$$
\text { Unins }_{i t}=f\left(\beta_{0}+\beta_{1} \ln \left(A V G R_{i t}\right)+\sum_{k=1}^{K} \delta_{k} \overline{\overline{E A R N}}_{k}+\gamma X_{i t}+\varepsilon_{i t}\right)
$$

The uninsured variable is one of seven different coverage measures:

1. an indicator for whether individual $i$ is ever uninsured during his/her time in the SIPP,

\footnotetext{
${ }^{15}$ Indeed, $A V G R$ is positively correlated (at the 99 percent confidence level) with the mean of earnings over one's career.

${ }^{16}$ I had trouble achieving convergence in the logit model when using a continuous measure of average predicted earnings (expressed in thousands of real dollars), so I instead use a categorical variable for each four- or five-year average, with each category representing either $\$ 5,000$ or $\$ 10,000$ ranges.
} 
2. an indicator for whether individual $i$ is always uninsured during his/her time in the SIPP,

3. the number of months individual $i$ lacks health insurance coverage during his/her time in the SIPP,

4. an indicator for whether individual $i$ is ever uninsured in a specific year (observations at the person-year level),

5. an indicator for whether individual $i$ is always uninsured in a specific year, ${ }^{17}$

6. the number of months individual $i$ lacks health insurance coverage in a specific year,

7. and whether the individual $i$ lacks health insurance coverage in a specific month.

In specifications $1,2,4,5$, and $7, f(\cdot)$ is the logistic function. There is bunching in the number of months uninsured, because many people are never uninsured, and others are uninsured throughout their time in the SIPP sample. Specifications 3 and 6 are therefore estimated by Tobit regression, with the lower censoring limit set at zero months for both models; the upper censoring limit is 12 months for specification 6 , and the maximum number of months one could be in the sample - 24 for most panels, except for 2004 (36) and 1996 (48) - for specification 3. The sample for the first three specifications includes one observation per person, one observation per person-year for the third through sixth specifications, and one per person-month for the last specification.

For each of these (nonlinear) regressions, I report the average marginal effect, or the mean of the derivative of the dependent variable with respect to $\ln (A V G R)$ across the regression sample, and its standard error (approximated by the Delta Method). In each

\footnotetext{
${ }^{17}$ This measure of insurance status is the most comparable to the Current Population Survey's health insurance variable, which is used to create the uninsured rate figure cited most often in policy discussions.
} 
case, my hypothesis is that the mean derivative, or marginal effect, of $\ln (A V G R)$ on the measure of being uninsured should be positive and statistically significant; i.e., greater earnings volatility over one's career (or the careers of one's family unit) should be associated with one being more likely to lack health insurance coverage at any point that one is observed.

The independent variables in each regression are measures of earnings volatility, the average level of predicted earnings over a period of four or five years (10 periods), and other individual characteristics. $A V G R$ enters equation (3) as a natural logarithm because of its long right tail. Average predicted earnings, $\overline{\widehat{E A R N}}$, are expressed in real (2000) dollars. $X$ includes age and its square, categorical variables for race (with Hispanic as a separate, mutually exclusive category), the SIPP panel (as some panels last longer, and thus allow more time to experience an uninsured spell), more detailed educational attainment categories, and the quintiles of wealth (as those with higher assets can better smooth consumption or buy insurance on the private market), and indicator variables for whether the individual has ever married, ever had children, is foreign-born, or is a homeowner.

Each regression is run separately for men and women, to allow for heterogeneous effects of individual or family earnings volatility on health insurance status. I also present results separately by age (18-29, 30-39, 40-49, and 50-64) at the time of first SIPP interview; $A V G R$ tends to increase slightly (though statistically significantly) with age, as there are more opportunities for random shocks as one ages. 
All regressions are weighted, using an adjusted version of the weight provided by SIPP to account for the oversampling of low-income individuals. I make this adjustment because the SIPP-provided weights were calculated on the full sample, but failed matches to the SSA data may not be random; ${ }^{18}$ moreover, I exclude other individuals, like the ever-self-employed and ever-divorced, that make the sample not nationally representative. ${ }^{19}$ I calculate the average monthly weight for each individual in the full Gold Standard File, including zero weights for months when the individual is missing from his or her SIPP panel. Then, I estimate a (weighted) logit regression for the probability of being included in the sample, and divide the average monthly SIPP weight by the predicted probability of inclusion. ${ }^{20}$

In all specifications, I use Huber-White heteroskedasticity-robust standard errors, and in specifications 4 through 7, standard errors are clustered at the individual level. ${ }^{21}$

Table 3 presents summary statistics for men and women, both unweighted and weighted. The difference between the unweighted (33 percent) and weighted (27

\footnotetext{
${ }^{18}$ Christia and Schwabish (2009) find slight differences between the full 1996 SIPP panel and the SIPP respondents whom they are able to match to the SSA records. The matched sample is slightly younger and less Hispanic than the full sample, but by most other characteristics they are similar.

${ }^{19}$ The adjustment to the SIPP weight does not account for the restriction that individuals have 10 or more years of positive earnings. Therefore, all results should be interpreted as nationally representative among relatively stable earners.

${ }^{20}$ The coefficients on $\ln (A V G R)$ in the insurance coverage models are generally larger (more positive) in weighted regressions compared to the same model unweighted, but there is no difference in the qualitative finding of statistical significance. The results are almost identical when I use alternative adjusted weights: when I adjust the average monthly weight to also account for the requirement that a worker needs 10 years of positive earnings to be included, and/or when the numerator of the adjusted weight is the weight from the first full month of the first wave of the SIPP panel.

${ }^{21}$ I do not adjust standard errors to account for the fact that the two key independent variables, $A V G R$ and $\overline{\overline{E A R N}}$, are generated regressors, but plan to correct this in the next version.
} 
percent) proportions that are ever uninsured during their time in the sample, and the decrease in the proportion lacking a high school degree from unweighted (12.7 percent) to weighted (7.8 percent), are evidence of the importance of weighting to account for oversampling of low-income individuals, who are more likely to be uninsured. ${ }^{22}$ Those who are ever uninsured during their time in the sample spend an average of 15 months uninsured, while those who are ever uninsured in a particular year spend about eight months uninsured that year. AVGR is heavily skewed to the right, as evidenced by its large standard deviation, though the mean and median (unreported) of $\ln (A V G R)$ are roughly equal, indicating that the log transformation has eliminated most of the skewness.

\section{Results}

In Table 4, I report the results of logit regressions of indicators for whether the matched worker is ever, or always, uninsured during his/her time in the SIPP sample on earnings volatility, the level of earnings throughout one's career, and personal characteristics. I do not report estimates for the level of earnings (almost universally negative, as expected), the SIPP panel fixed effects, nor the constant. The first two lines of Table 4 are the means of each individual's marginal effect of $\ln (A V G R)$ on the probability of being

\footnotetext{
22 The weighted uninsured rates in Table 3 are a close match for the uninsured rates for the SIPP panel in 2002, found in the Economic Research Initiative on the Uninsured's Fast Facts Tables, http://www.rwjferiu.org/fastfacts/index.html. The proportion of workers aged 18 to 64 that were ever uninsured in 2002 is 25.2 percent, and the proportion who were uninsured for the entire year was 9.1 percent, according to ERIU. The respective proportions in this sample are 20.0 and 7.9 percent. It is no surprise that these rates are somewhat smaller in this paper. First, the sample is drawn from 1990 through 2006, and the uninsured rate has grown over time, so 2002 is near the peak. Second, due to the sample selection criterion that requires at least 10 years of positive earnings, this sample is more stable, and thus more likely to be insured, than the working population overall.
} 
uninsured ever or always and their Delta-method standard errors, while the rest of the table reports logit coefficients and standard errors.

The first two columns of Table 4 contain the main result of this paper: as career earnings volatility increases, one is more likely to ever experience a period without health insurance coverage within a two- to four-year period of observation. This effect is highly statistically significant for both genders, though the magnitude of the effect is nearly twice as large for men, as expected. ${ }^{23}$

The mean derivative implies that, on average, a 1 percent increase in the volatility measure $A V G R$, all else equal, would increase the probability of experiencing an uninsured episode during the SIPP sampling period by 0.09 percentage points. Interpreting this magnitude is somewhat difficult, though, because the reader is likely not familiar with how real-life earnings variation translates into changes in the average square root of the sum of squared residuals from a regression of real earnings on a cubic function of age, denominated in the natural log of dollars per year.

To assist in the interpretation of these coefficients, I consider a counterfactual. I replace every matched worker's highest earning year from the SSA-IRS record with zero earnings, as if the worker was laid off at the height of his or her career and spent the year unemployed, but then resumed his or her career without scarring. Then, in order to hold constant the average (predicted) earnings level in that five-year block, I spread those

\footnotetext{
${ }^{23}$ The coefficients on the other covariates are in line with existing research. One is more likely to be uninsured if one is non-white (especially Hispanic), unmarried, young, poor (including not owning a home), or less educated.
} 
earnings over the other four (or three) years in the five (or four)-year age block. ${ }^{24}$ I then recalculate $A V G R$ for the full sample. This recalculated $A V G R$ is a median of 24.1 percent, or about $\$ 1,600$ per year, larger than the actual $A V G R .^{25}$ Multiplying 24.1 percent (because $A V G R$ enters as a natural log) by the mean derivative suggests that such a reshuffling of earnings - at any point in one's career, not just coincident with SIPP sampling - would result in a man being on average 2.3 percentage points more likely to be uninsured at some point while he's observed in the SIPP, while a woman is on average 1.4 percentage points more likely. Compared to a mean of 29 or 25 percent, respectively, the magnitudes are fairly substantial.

The results in the third and fourth columns of Table 4 indicate that earnings volatility is not associated with being continuously uninsured during the observation period. The mean marginal effect is positive but not statistically significant for both men and women, and the magnitudes are not very large; replacing one's best earnings year with zero earnings, as above, would increase the probability of always being uninsured by 0.04 percentage points for men and 0.11 percentage points for women. While the lack of an effect may seem surprising, given the strong estimated effect for ever being uninsured, high earnings volatility implies that at least some years are above one’s longterm trend. There is little reason, then, that someone who has inconsistent earnings should also be persistently uninsured.

\footnotetext{
${ }^{24}$ Alternatively, if I were to add the maximum annual earnings to the next year (or the previous year if the next year is part of a different five-year age block), the recalculated $A V G R$ is 31.3 percent larger. Just deleting the maximum annual earnings increases the $A V G R$ by 11.7 percent.

${ }^{25}$ In the simulation, the mean change to $A V G R$ is even larger - an additional \$2,185 per year above the actual $A V G R$, an increase of 38.5 percent
} 
A potential concern with the earnings volatility metric $A V G R$ is that it is measuring something different for workers of varying ages. For young workers who have not accumulated much experience, $A V G R$ is limited to measuring contemporaneous earnings volatility and thus, to the extent that volatility arises from periods of unemployment or underemployment where employee benefits are rare, should be strongly correlated with being uninsured. ${ }^{26}$ In addition, specifying the (predicted) earnings level as a four- or five-year average does not capture the age-earnings profile for someone without much experience beyond four or five years. These measures should better capture the long-run trend of earnings, and year-to-year deviance from this trend, for older workers.

The marginal effect estimates presented in the first two columns of Table 5 suggest that, though the magnitude of the correlation diminishes with age, greater longrun earnings volatility increases the likelihood of ever being uninsured even for older, established workers. The mean derivative is 0.15 for men under age 30 , falling to 0.10 for men in their 30s and 40s, and remains at a statistically significant 0.06 for men over age 50. Women experience a similar pattern, though the estimated effect is actually slightly larger for women ages 30-39 than for women under 30. Though the declining pattern for each gender is obvious, none of the differences between consecutive estimates are statistically significant. These estimates suggest a 1.5- or 1.0-percentage-point increase in the probability of being uninsured for men and women, respectively, over age 50, when the highest earning year is reduced to zero.

\footnotetext{
${ }^{26}$ This is not strictly true for people who are in the SIPP at a young age, but afterward accumulate more years of recorded earnings, such as those 18-to-29-year-olds in the 1990-1993 panels.
} 
Table 5 also includes separate estimates by marital status and fertility history. Not surprisingly, the correlation between health insurance coverage and earnings volatility is stronger (with $p$-value less than .01 for men and less than .05 for women) for never-married individuals than for those who are in their first marriage at the time they are in the SIPP, a result that emphasizes the importance of having a spouse to cushion the shock of earnings losses. Married women with children, as measured by $A V G R$, have more volatile earnings than unmarried women and women who haven't had children (by the time of SIPP sampling) due to the increased prevalence of gaps in their earnings records, but the relationship between volatility and coverage is weakest for this group, suggesting that working husbands’ earnings, and their employer-sponsored insurance, protect against the consequences these gaps (or allow them to happen). Never-married women with volatile earnings histories are more likely to also be uninsured if they have had children than if they have not, which is likely a selection effect.

In the third and fourth columns of Table 5, the dependent variable is the number of months uninsured during one's time in the SIPP sample, estimated by Tobit regression (which accounts for the large proportion who are never uninsured). For every subsample, the correlation between months uninsured and earnings volatility is positive and highly statistically significant, but some of the patterns observed in the magnitudes of the effects across groups disappear. The first two columns indicate that the same increase in volatility will be associated with larger increases in the probability of being uninsured for the young than for the old, but the Tobit results suggest that the young will experience smaller increases in the time spent uninsured; these findings are consistent with the young experiencing short, frequent gaps in coverage. The same is true for never-married 
women: those without children have slightly more reliable coverage, but spend a longer time uninsured when coverage lapses. Other patterns are consistent across coverage measures, though they lose their statistically significant differences: men spend more time uninsured than women with comparable volatility, as do married, childless women compared to married women with children.

Table 6 presents analogous results where the sample is, instead, person-year observations. In the top panel, the two dependent variables are an indicator for whether the matched worker was ever uninsured during that year (first two columns), and the number of months spent uninsured that year (third and fourth columns). ${ }^{27}$ The results for uninsured ever during the year are similar to ever uninsured during the full sample, though smaller in magnitude, as expected. For men, a 24.1-percent increase in the earnings volatility measure (in line with the counterfactual outlined above) is associated with a statistically significant 1.7 percentage-point increase, or about 8 percent of the mean of 21 percentage points, in the probability of being uninsured at some point in the given year. The increase for women is smaller but also statistically significant, leading to an increase of 1.0 percentage points in the same exercise. As before, the correlation between the time spent uninsured and earnings volatility is stronger for men than for women. The other patterns across subsamples are similar to what is observed in Table 5, except that the correlation between volatility and missing coverage that year is stronger for the oldest cohort of men than for any other group.

\footnotetext{
${ }^{27}$ The SIPP Gold Standard File currently eliminates any years where the SIPP began or ended in the middle of the calendar year, so if someone is uninsured all year, that means he or she is uninsured for all 12 calendar months, not just for all the months he or she was present in the SIPP during that calendar year.
} 
In the middle panel of Table 6, the dependent variable is instead whether the individual is uninsured all year. Like the results in Table 5, the magnitudes of these marginal effects are smaller than the magnitude for the "ever uninsured in the year" regression, but unlike the previous results, the effect is positive and statistically significant. Similarly, the estimates in the bottom panel indicate that both men and women with high earnings volatility are also more likely to be uninsured in any given month, though the magnitude is not as large as when the sample is once per person-year or once per person.

Robustness checks. One concern with the data is that before 1978, reported earnings are capped at the Social Security taxable maximum. From 1947 to 1977, the median nominal personal income for men over age 15 was only, on average, 23 percent higher than the taxable maximum, and in one year (1965) was actually lower. ${ }^{28}$ Beginning with 1978 , the Gold Standard File includes the Social Security Detailed Earnings Record, which includes uncapped W-2 earnings, both deferred and non-deferred and both covered and exempt from the FICA tax.

Because of this change in the completeness of earnings data, any worker who earns more than the taxable maximum both before and after 1978 will appear to have a more volatile earnings history than they would have otherwise. To some extent, the volatility calculation accounts for this jump in earnings. Recall that the volatility measure is the mean absolute deviation from the trend in earnings fitted by a cubic

\footnotetext{
${ }^{28}$ FICA taxable maximum time series is from the SSA Annual Statistical Supplement, 2009, Table 2.A.3. Median nominal personal income for men and women is from the U.S. Census Bureau, Table P-08-AR, http://www.census.gov/hhes/www/income/data/historical/people/P08AR_2009.xls, last accessed 1/21/11. After 1978, the taxable maximum was two- to three-times men's median personal income.
} 
function of age, and that the trend is fitted separately by gender, birth cohort, and whether the individual completed college. Because the cohorts are separate, including a control for age is identical to controlling for year fixed effects. For example, many collegeeducated men born in 1930 will see a shift up in reported earnings in 1978, but the age cubic will account for the shift just as if an economic boom had induced a secular upward earnings shift that same year; what matter is the deviation from the predicted earnings level, which is likely higher than the 1978 taxable maximum because of the prevalence of higher earners among this group.

Still, because there is likely heterogeneity in the likelihood of exceeding the taxable maximum within the gender-education-birth cohort cells, and because upward earnings variation has a greater effect on the volatility measure after 1978, I calculate an alternative measure of earnings volatility that considers only the 1978-2006 period. The first two columns of Table 7 present the results of a re-estimation of the main regression model with this alternative $A V G R$ measure. The estimates are very similar to the analogous results in Table 5; the marginal effect of volatility on the probability of ever being uninsured is slightly smaller for men, but nearly identical for women and most of the more defined subsamples, and each estimate is significantly different from zero at the 99 percent confidence level.

Another potential problem with $A V G R$ is the decision to calculate the earnings volatility from the combined earnings of a married couple in each year, while calculating volatility just from the individual's earnings for someone who has never married. The implicit model is that all financial resources and health coverage are shared between spouses. This need not be the case: a married worker may be eligible for only individual 
coverage, or find family coverage unaffordable (especially for childless couples who, in one-size-fits-all family coverage, have to subsidize larger families), so when a spouse loses a job, the spouse becomes uninsured. This method is also subject to measurement error: I combine a couple’s earnings for all years, not just the years in which they were married, as I do not know whether and for how long they were sharing resources before they were married (if, for instance, they were cohabitating). Additionally, the volatility measure may be sufficiently different in scale between married couples and nevermarried individuals that the effect of volatility on insurance coverage should be specified differently between the groups; indeed, the estimated effects in Table 5 are statistically different between the ever- and never-married at a high confidence level for both genders.

The third and fourth columns of Table 7 present re-estimated results using the earnings volatility measure calculated only on an individual's earnings, regardless of marital status. The estimates are just slightly smaller for married men (and obviously identical for never-married men). While the magnitude of the estimated marginal effect fell by half for married women, it remains statistically significant, though at a lesser confidence level for married women with children. The ever-divorced, excluded from the previous analysis because it was unclear what their combined earnings would be in the years they were married, look like the never-married group, with a high estimated effect of volatility on insurance coverage, likely because of greater exposure to job insecurity. 


\section{Conclusion}

To my knowledge, this is the first paper to examine the relationship between long-run earnings volatility and short- and medium-run health insurance coverage. I use a new, large-scale dataset, the SIPP Gold Standard File, which links a worker's earning history from administrative data to rich personal and family information from a longitudinal household survey. The results indicate that workers who have more volatile family earnings are more likely to experience a period without health insurance coverage. This correlation is stronger for men than for women, for the never married than for the married, and for the young than for older workers.

While I find a robust association between earnings volatility and health insurance coverage, this does not imply causality; the results are consistent with high career earnings volatility resulting in one more likely to be uninsured, being uninsured making career earnings more volatile, and/or a third factor both increasing the likelihood of being uninsured and increasing the volatility of career earnings. Unfortunately, the SIPP Gold Standard File data does not allow for conclusions about causality. It is possible, and quite likely, that someone who is uninsured now is at greater risk of being uninsured in the future, and vice versa. To be able to assert that earnings volatility causes future gaps in coverage, or the converse, one would need to be able to observe not just the worker's earnings history, but also his/her insurance status in those same years. Currently, no dataset allows for a long enough time series of individual coverage to make this case, though as time goes on, the Panel Survey of Income Dynamics, which began collecting health insurance coverage status in 1997, will have enough years of data to better answer this question. 
Taking these results at face value, there appears to be a relationship between an inconsistent career earnings profile and the consistency of health insurance coverage. These findings are consistent with other work showing that job losses lead to enduring "scars" that may affect future economic success. Though much has been done in recent years to help workers in down years, including COBRA health insurance coverage and unemployment insurance benefit extensions, policymakers should consider ways to strengthen the safety net, including increasing the funding for job training and adult education programs or encouraging temporary or contract work as a bridge, so that temporary setbacks in one's career do not lead to lasting negative outcomes.

\section{References}

Abowd, John M., Martha Stinson and Gary Benedetto. 2006. "Final Report to the Social Security Administration on the SIPP/SSA/IRS Public Use File Project," http://www.census.gov/sipp/SSAfinal.pdf

Bils, Mark J. 1985. "Real Wages Over the Business Cycle: Evidence from Panel Data," Journal of Political Economy 93(4): 666-689.

Cameron, Stephen and Joseph Tracy. 1998. "Earnings Instability in the United States: An Examination Using Matched-CPS Data,” Federal Reserve Bank of New York working paper, http://www.newyorkfed.org/research/economists/tracy/earnings_variability.pdf.

Christia, Julian and Jonathan A. Schwabish. 2009. "Measurement Error in the SIPP: Evidence from Matched Administrative Records," Journal of Economic and Social Measurement 34: 1-17.

Czajka, John L. and Cara Olsen. 2000. "The Effects of Trigger Events on Changes in Children's Health Insurance Coverage.” Princeton, NJ: Mathematica Policy Research, Inc. 
Dahl, Molly, Thomas DeLeire, and Jonathan A. Schwabish. 2008. Recent Trends in the Variability of Individual Earnings and Household Income. Congressional Budget Office Paper, http://www.cbo.gov/ftpdocs/95xx/doc9507/06-30-Variability.pdf.

DeNavas-Walt, Carmen, Bernadette D. Proctor, and Jessica C. Smith. 2009. "Income, Poverty, and Health Insurance Coverage in the United States: 2008,” U.S. Census Bureau Report P60-236.

Devereux, Paul J. and Robert A. Hart. 2006. "Real Wage Cyclicality of Job Stayers, Within-Company Job Movers, and Between-Company Job Movers,” Industrial and Labor Relations Review 60(1): 105-119.

Dynan, Karen E., Douglas W. Elmendorf, and Daniel E. Sichel. 2008. "The Evolution of Household Income Volatility.” Federal Reserve Board, Finance and Economics Discussion Series, Working Paper 2007-61, http://www.federalreserve.gov/Pubs/feds/2007/200761/200761pap.pdf.

Ellwood, David T. 1982. "Teenage Unemployment: Permanent Scars or Temporary Blemishes?" in The Youth Labor Market: Its Nature, Causes and Consequences, edited by R. B. Freeman and D. A. Wise, 349-85. Chicago: University of Chicago Press.

Fallick, Bruce C. 1996. "A Review of the Recent Empirical Literature on Displaced Workers,” Industrial and Labor Relations Review 50(1): 5-16.

Goldin, Claudia. 2006. "The Quiet Revolution that Transformed Women’s Employment, Education, and Family,” The American Economic Review 96(2): 1-21.

Gottschalk, Peter and Robert Moffitt. 1994. "The Growth of Earnings Instability in the U.S. Labor Market,” Brookings Papers on Economic Activity, 1994(2): 217-272.

Gottschalk, Peter and Robert Moffitt. 2008. "Trends in the Transitory Variance of Male Earnings in the U.S., 1970-2004,” mimeo.

Gruber, Jonathan and Brigitte Madrian. 1997. "Employment Separation and Health Insurance,” Journal of Public Economics, 66:349-382

Haider, Steven J. 2001. "Earnings Instability and Earnings Inequality of Males in the United States: 1967-1991,” Journal of Labor Economics 19(4): 799-836.

Hurst, Erik, Geng Li, and Benjamin Pugsley. 2010. "Are Household Surveys Like Tax Forms: Evidence from Income Underreporting of the Self Employed,” NBER Working Paper 16527.

Kahn, Lisa B. 2010. "The Long-Term Labor-Market Consequences of Graduating from College in a Recession,” Labour Economics 17(2): 303-316. 
Kuttner, Hanns and Matthew S. Rutledge. 2007. "Higher Income and Uninsured: Common or Rare?” Health Affairs 26(6): 1745-1752.

Jacobson, Louis, Robert LaLonde, and Daniel Sullivan. 1993. The Costs of Worker Displacement. Kalamazoo, MI: The W.E. Upjohn Institute for Employment Research.

Moffitt, Robert A. and Peter Gottschalk. 1995. "Trends in the Covariance Structure of Earnings in the U.S., 1969-1987,” mimeo.

Moffitt, Robert A. and Peter Gottschalk. 2002. "Trends in the Transitory Variance of Earnings in the United States,” Economic Journal 112: C68-73.

Ruhm, Christopher. 1991. “Are Workers Permanently Scarred by Job Displacement?” The American Economic Review, 81(1):319-324.

Shin, Donggyun. 1994. "Cyclicality of Real Wages Among Young Men,” Economics Letters 46(2): 137-142.

Shin, Donggyun and Gary Solon. 2008. “Trends in Men’s Earnings Volatility: What does the Panel Study of Income Dynamics Show?” NBER Working Paper 14075.

Short, Pamela Farley and Deborah R. Graefe, 2003. "Battery-Powered Health Insurance? Stability in Coverage of the Uninsured,” Health Affairs 22(6): 244-255.

Simon, Kosali and Mathis Schroeder. 2006. “The Effect of Involuntary Job Displacement on Health Insurance,” draft presented at ERIU Conference, September 7-8, 2006.

Social Security Administration. 2009. Annual Statistical Supplement to the Social Security Bulletin.

Stevens, Ann Huff. 1997. "Persistent Effects of Job Displacement: The Importance of Multiple Job Losses,” Journal of Labor Economics 15(1): 165-188.

Stevens, Ann Huff. 2001. "Changes in Earnings Instability and Job Loss,” Industrial and Labor Relations Review, 55(1):60-78. 
Figure 1. Hypothetical Age-Earnings Profiles, by Variance

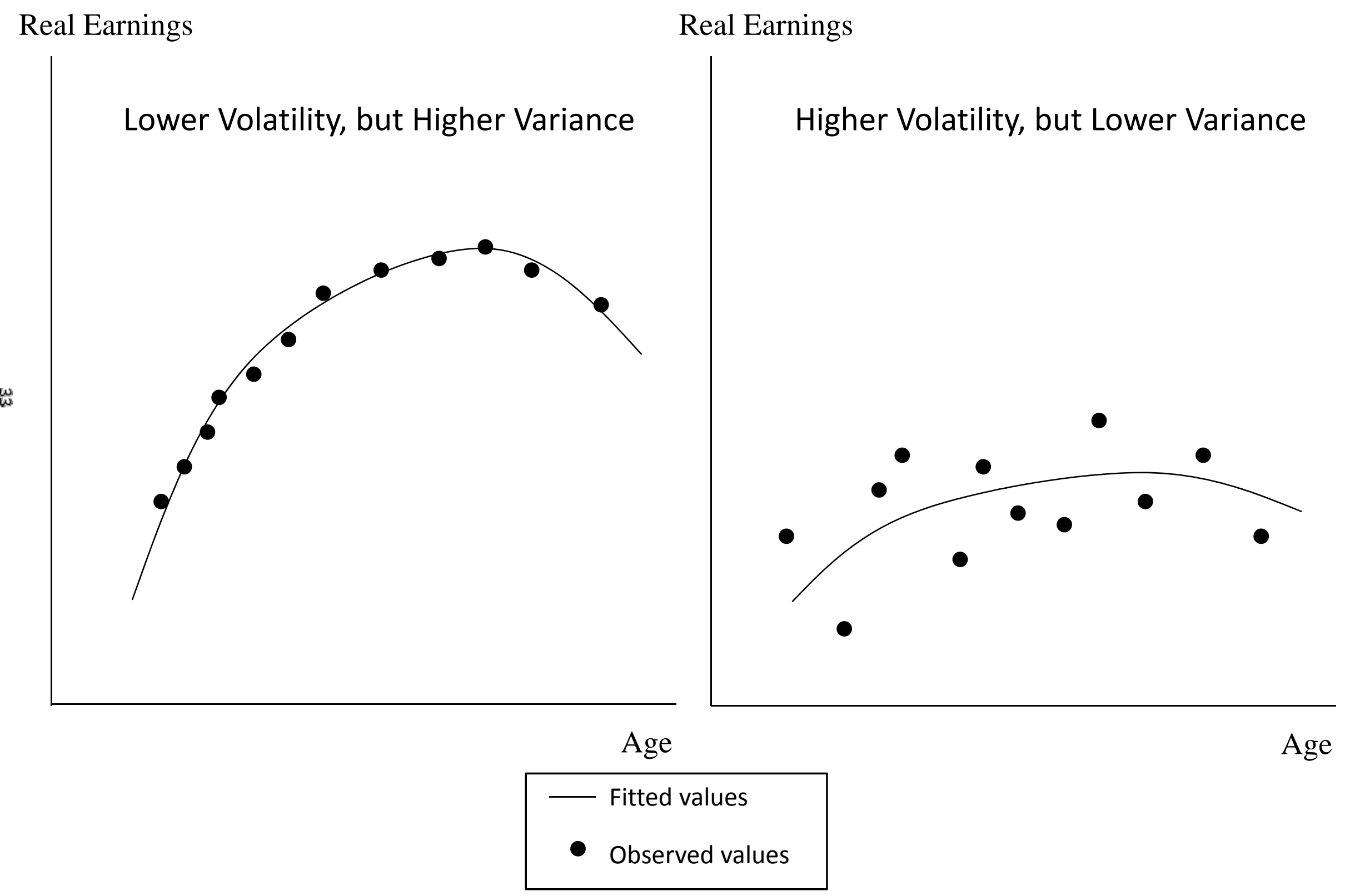


Figure 2. Hypothetical Age-Earnings Profiles, by Sum of Squared Residuals

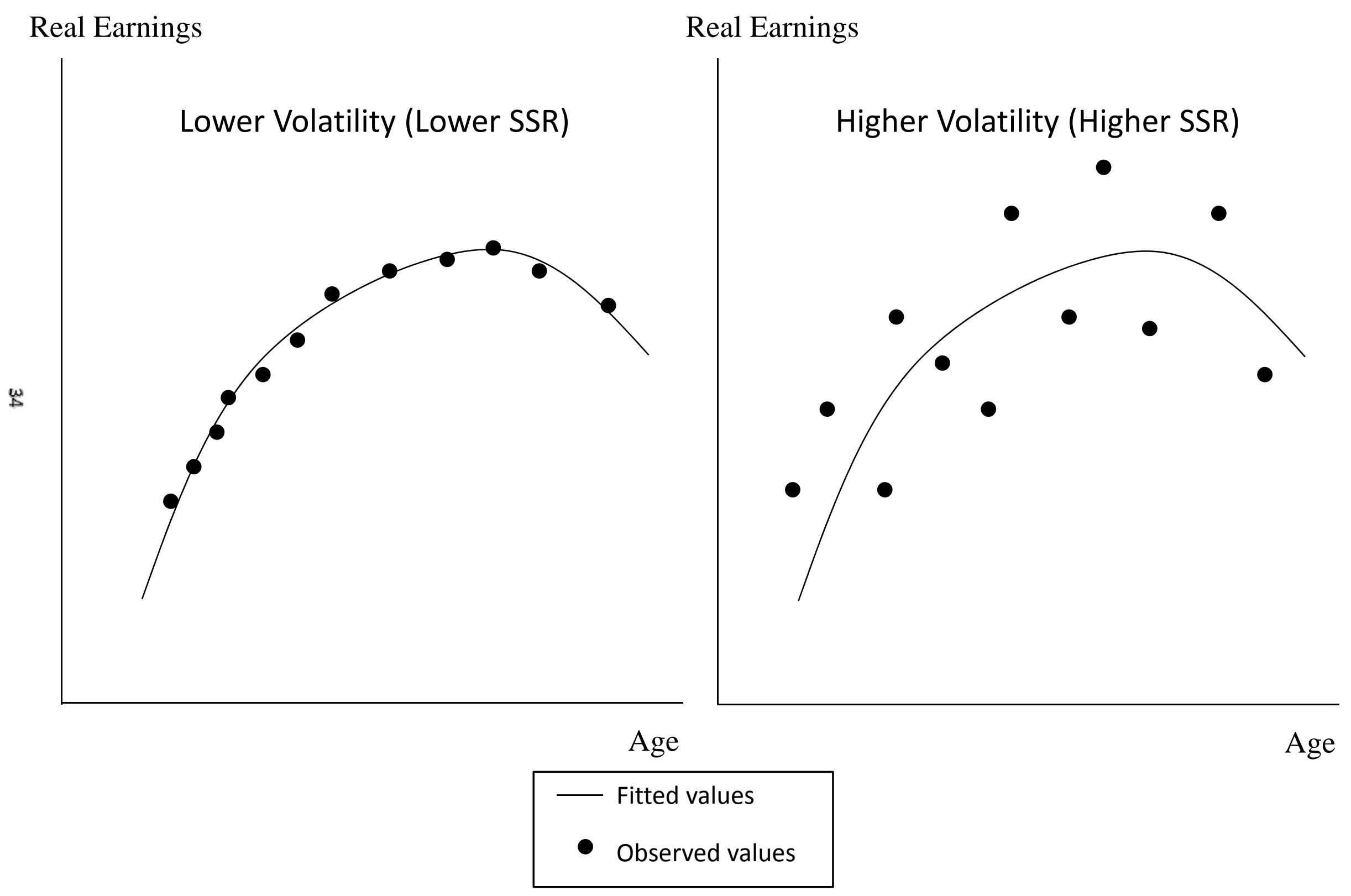


Table 1. Eligible Birth Cohorts, by SIPP Panel

\begin{tabular}{|c|c|c|c|}
\hline \multirow[b]{2}{*}{ SIPP Panel } & \multirow[b]{2}{*}{ First Cohort } & \multicolumn{2}{|c|}{ Last Cohort } \\
\hline & & $\begin{array}{c}\text { Some College or } \\
\text { Less }\end{array}$ & $\begin{array}{c}\text { College Degree } \\
\text { or More }\end{array}$ \\
\hline 1990 & 1927 & 1972 & 1968 \\
\hline 1991 & 1928 & 1973 & 1969 \\
\hline 1992 & 1929 & 1974 & 1970 \\
\hline 1993 & 1930 & 1975 & 1971 \\
\hline 1996 & 1935 & 1978 & 1974 \\
\hline 2001 & 1938 & 1979* & 1979 \\
\hline 2004 & 1942 & 1979* & 1979* \\
\hline
\end{tabular}

Note: ${ }^{*}=$ Requirement that workers have 10 or more years of earnings is binding for all workers born after 1

Table 2. Refining the Sample

Initial Sample Size

349,089

- Missing link to SSA data

91,950

- Fewer than 10 years of positive earnings

25,155

- Ever report self-employment earnings

86,624

- Ever divorced, missing education, or invalid adjusted SIPP weight

41,392

$=$ In Sample

103,968 
Table 3. Summary Statistics

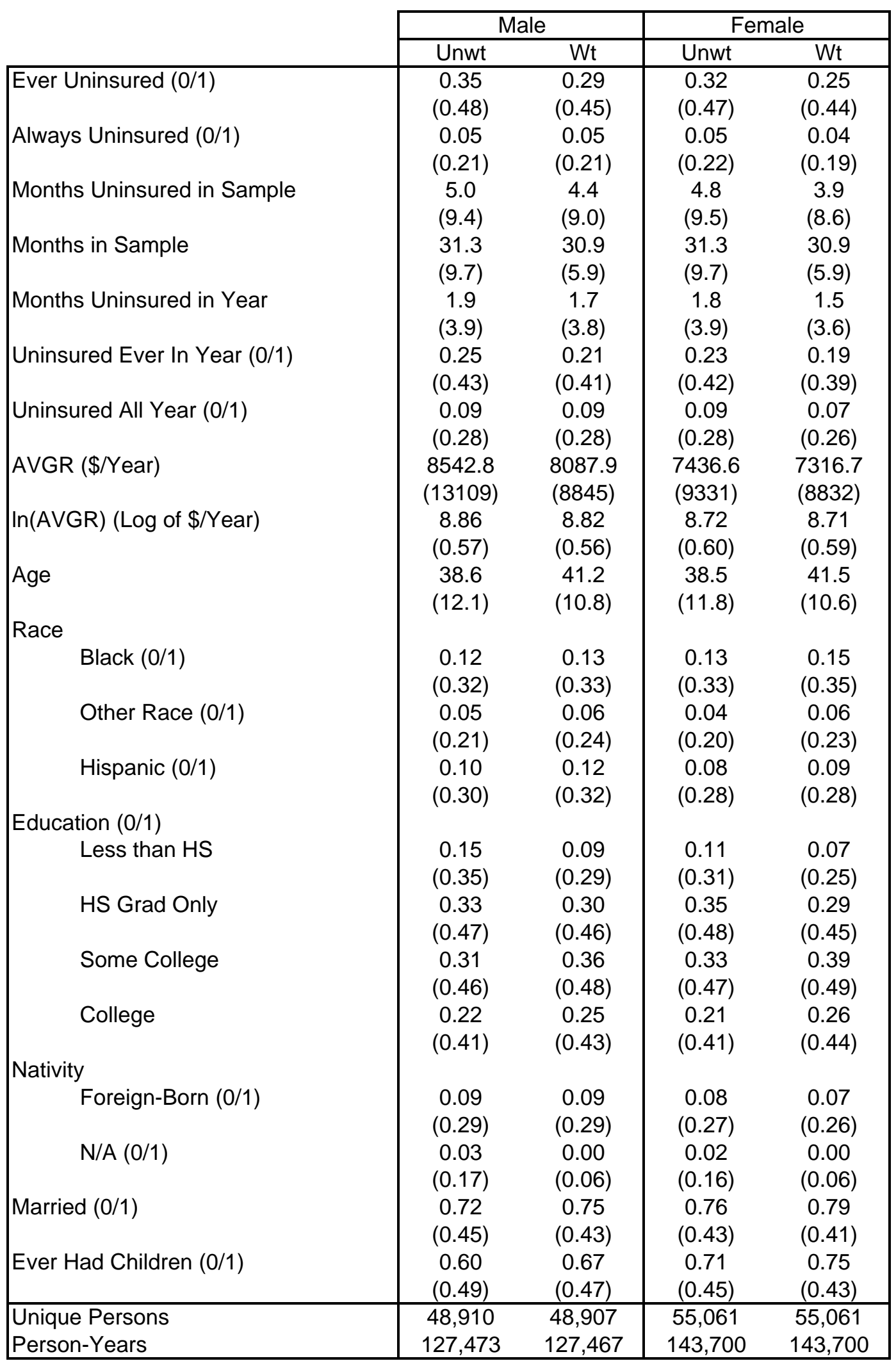

Note: Standard Deviations in parentheses. 
Table 4. Logit Regression Results, One Observation Per Person

\begin{tabular}{|c|c|c|c|c|}
\hline \multirow[t]{3}{*}{ Dependent Variable } & \multicolumn{2}{|c|}{ Ever Uninsured } & \multicolumn{2}{|c|}{ Always Uninsured } \\
\hline & Men & Women & Men & Women \\
\hline & (1) & (2) & (3) & (4) \\
\hline Mean Derivative & & & & \\
\hline $\ln (\mathrm{AV}$ & $\begin{array}{l}0.094 \text { *** } \\
(0.007)\end{array}$ & $\begin{array}{l}0.058 \text { *** } \\
(0.007)\end{array}$ & $\begin{array}{r}0.0018 \\
(0.0043)\end{array}$ & $\begin{array}{r}0.0048 \\
(0.0041)\end{array}$ \\
\hline Logit Coefficients & & & & \\
\hline $\ln (A \vee G R)$ & $\begin{array}{l}0.779 \text { *** } \\
(0.063)\end{array}$ & $\begin{array}{l}0.466 \text { *** } \\
(0.057)\end{array}$ & $\begin{array}{r}0.052 \\
(0.125)\end{array}$ & $\begin{array}{r}0.151 \\
(0.130)\end{array}$ \\
\hline Age & $\begin{array}{l}-0.196 \text { ***} \\
(0.043)\end{array}$ & $\begin{array}{l}-0.142 \text { *** } \\
(0.035)\end{array}$ & $\begin{array}{r}-0.061 \\
(0.081)\end{array}$ & $\begin{array}{r}-0.107 \\
(0.082)\end{array}$ \\
\hline Age Squared & $\begin{array}{l}0.0019 \text { *** } \\
(0.0005)\end{array}$ & $\begin{array}{l}0.0008 \text { ** } \\
(0.0004)\end{array}$ & $\begin{array}{l}0.0011 \\
(0.001)\end{array}$ & $\begin{array}{l}0.0009 \\
(0.001)\end{array}$ \\
\hline Black & $\begin{array}{r}0.110 \\
(0.079)\end{array}$ & $\begin{array}{l}0.442 \text { *** } \\
(0.072)\end{array}$ & $\begin{array}{l}-0.027 \\
(0.140)\end{array}$ & $\begin{array}{r}0.082 \\
(0.145)\end{array}$ \\
\hline Other Race & $\begin{array}{r}0.154 \\
(0.117)\end{array}$ & $\begin{array}{l}0.304 \\
(0.111)\end{array}$ & $\begin{array}{r}0.142 \\
(0.225)\end{array}$ & $\begin{array}{r}0.159 \\
(0.227)\end{array}$ \\
\hline Hispanic & $\begin{array}{l}0.494 \\
(0.093)\end{array}$ & $\begin{array}{l}0.451 \text { *** } \\
(0.089)\end{array}$ & $\begin{array}{r}0.096 \\
(0.157)\end{array}$ & $\begin{array}{l}0.344 \\
(0.172)\end{array}$ \\
\hline Less Than HS & $\begin{array}{l}0.895 \text { *** } \\
(0.133)\end{array}$ & $\begin{array}{l}2.108 \text { *** } \\
(0.123)\end{array}$ & $\begin{array}{l}1.092 \text { *** } \\
(0.293)\end{array}$ & $\begin{array}{l}2.264 \text { *** } \\
(0.351)\end{array}$ \\
\hline HS Grad Only & $\begin{array}{l}0.347^{\text {*** }} \\
(0.116)\end{array}$ & $\begin{array}{l}1.131 \\
(0.102)\end{array}$ & $\begin{array}{c}0.574 \\
(0.290)\end{array}$ & $\begin{array}{l}1.541 \text { *** } \\
(0.337)\end{array}$ \\
\hline Some College & $\begin{array}{r}0.165 \\
(0.113)\end{array}$ & $\begin{array}{l}0.813 \text { *** } \\
(0.102)\end{array}$ & $\begin{array}{r}0.293 \\
(0.288)\end{array}$ & $\begin{array}{l}1.366 \text { *** } \\
(0.336)\end{array}$ \\
\hline Foreign-Born & $\begin{array}{l}0.179 \text { * } \\
(0.096)\end{array}$ & $\begin{array}{r}0.071 \\
(0.096)\end{array}$ & $\begin{array}{l}0.522 \\
(0.188)\end{array}$ & $\begin{array}{r}0.202 \\
(0.180)\end{array}$ \\
\hline Married & $\begin{array}{l}-0.335 * \star \star \\
(0.081)\end{array}$ & $\begin{array}{l}-0.726 \text { *** } \\
(0.070)\end{array}$ & $\begin{array}{l}-0.429 * * * \\
(0.143)\end{array}$ & $\begin{array}{l}-0.914 \text { *** } \\
(0.146)\end{array}$ \\
\hline Ever Had Children & $\begin{array}{r}0.077 \\
(0.072)\end{array}$ & $\begin{array}{r}0.069 \\
(0.069)\end{array}$ & $\begin{array}{c}0.226 \text { * } \\
(0.137)\end{array}$ & $\begin{array}{r}0.082 \\
(0.151)\end{array}$ \\
\hline Total Wealth & & & & \\
\hline 2nd quintile & $\begin{array}{l}-0.281 \text { *** } \\
(0.082)\end{array}$ & $\begin{array}{l}-0.263 \text { *** } \\
(0.078)\end{array}$ & $\begin{array}{r}-0.108 \\
(0.135)\end{array}$ & $\begin{array}{l}-0.341 \text { ** } \\
(0.137)\end{array}$ \\
\hline 3rd quintile & $\begin{array}{l}-0.611 \\
(0.091)\end{array}$ & $\begin{array}{l}-0.632 \text { *** } \\
(0.086)\end{array}$ & $\begin{array}{l}-0.593 \\
(0.178)\end{array}$ & $\begin{array}{l}-0.745 \text { *** } \\
(0.178)\end{array}$ \\
\hline 4th quintile & $\begin{array}{l}-0.563 \text { ***} \\
(0.097)\end{array}$ & $\begin{array}{l}-0.863 \text { *** } \\
(0.089)\end{array}$ & $\begin{array}{l}-0.484 \text { ** } \\
(0.204)\end{array}$ & $\begin{array}{l}-1.138 \text { *** } \\
(0.197)\end{array}$ \\
\hline 5th quintile & $\begin{array}{l}-0.877 * * * \\
(0.102)\end{array}$ & $\begin{array}{l}-1.245 * * * \\
(0.093)\end{array}$ & $\begin{array}{l}-0.833 \text { *** } \\
(0.227)\end{array}$ & $\begin{array}{l}-1.410 \text { *** } \\
(0.240)\end{array}$ \\
\hline Zero or N/A Wealth & $\begin{array}{r}0.188 \\
(0.151)\end{array}$ & $\begin{array}{l}-0.217 \text { * } \\
(0.124)\end{array}$ & $\begin{array}{r}1.800 \\
(1.179)\end{array}$ & \\
\hline Homeowner & $\begin{array}{l}-0.210 \text { ***} \\
(0.070)\end{array}$ & $\begin{array}{l}-0.231 * \star \star \\
(0.069)\end{array}$ & $\begin{array}{r}0.0098 \\
(0.1327)\end{array}$ & $\begin{array}{r}0.118 \\
(0.135)\end{array}$ \\
\hline N/A Homeowner & 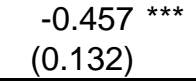 & $\begin{array}{l}-0.391 * \star \star \\
(0.104)\end{array}$ & $\begin{array}{l}-5.140 \text { *** } \\
(1.016)\end{array}$ & $\begin{array}{l}-3.894 \\
(0.483)\end{array}$ \\
\hline Number of Per & 48,907 & 55,061 & 48,907 & 51,973 \\
\hline $\mathrm{R}^{2}$ & 0.368 & 0.307 & 0.335 & 0.304 \\
\hline
\end{tabular}

Note: Regressions reported above use adjusted SIPP weights and include average predicted earnings over four- to five-year age groups, SIPP panel fixed effects, and a constant. Heteroskedasticity-robust standard errors in parentheses.

*** - Significantly different from zero at the 99 percent confidence level ${ }^{* *}$ - 95 percent confidence level * -90 percent confidence level 
Table 5. Regression Results for One Observation Per Person, By Gender, Age, and Family Structure

\begin{tabular}{|c|c|c|c|c|c|}
\hline \multirow{3}{*}{ Males } & \multicolumn{4}{|c|}{ Mean Derivative of $\ln (\mathrm{AVGR})$} & \multirow{2}{*}{$\mathrm{N}$} \\
\hline & \multicolumn{2}{|c|}{ Ever Uninsured (Logit) } & \multicolumn{2}{|c|}{ Months Uninsured (Tobit) } & \\
\hline & & & & & \\
\hline All & 0.094 & $(0.007) * \star \star$ & 5.37 & $(0.45) * * *$ & 48,907 \\
\hline Age $18-29$ & 0.145 & $(0.026) * * *$ & 4.55 & $(0.87) * \star *$ & 11,080 \\
\hline Age $30-39$ & 0.105 & $(0.014) * \star \star$ & 5.92 & $(0.76) * \star \star$ & 13,282 \\
\hline Age $40-49$ & 0.097 & $(0.013) * * *$ & 6.10 & $(0.95) * * \star$ & 12,059 \\
\hline Age $50-64$ & 0.061 & $(0.013) * \star *$ & 5.33 & $(0.04) * * \star$ & 12,401 \\
\hline Never Married & 0.155 & $(0.016) * \star \star$ & 5.98 & $(0.69) * \star \star$ & 13,502 \\
\hline On First Marriage & 0.071 & $(0.008) * * *$ & 5.05 & $(0.61) * \star \star$ & 35,378 \\
\hline \multicolumn{6}{|l|}{ Females } \\
\hline All & 0.058 & $(0.007) * * *$ & 3.89 & $(0.48) * * *$ & 55,061 \\
\hline Age 18-29 & 0.062 & $(0.028) * *$ & 2.52 & $(0.88) * \star \star$ & 11,988 \\
\hline Age $30-39$ & 0.069 & $(0.013) * * \star$ & 3.95 & $(0.83) * * \star$ & 15,524 \\
\hline Age $40-49$ & 0.055 & $(0.012) * \star *$ & 4.30 & $(0.93) * \star *$ & 14,009 \\
\hline Age $50-64$ & 0.042 & $(0.010) * * \star$ & 4.49 & $(0.05) * \star \star$ & 13,423 \\
\hline Never Married & 0.102 & $(0.017) * * *$ & 3.71 & $(0.72) * * \star$ & 12,996 \\
\hline On First Marriage & 0.044 & $(0.007) * * \star$ & 3.54 & $(0.62) * \star \star$ & 42,033 \\
\hline Ever Had Children & 0.052 & $(0.008) * * \star$ & 3.64 & $(0.58) * \star \star$ & 39,013 \\
\hline Never Had Children & 0.076 & $(0.014) * * *$ & 4.30 & $(0.81) * * *$ & 16,040 \\
\hline Ever Married, Had Children & 0.043 & $(0.008) * * *$ & 3.44 & $(0.68) * \star \star$ & 35,142 \\
\hline Ever Married, No Children & 0.054 & $(0.017) * \star \star$ & 4.39 & 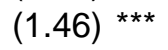 & 6,883 \\
\hline Never Married, Had Children & 0.117 & $(0.026) * \star \star$ & 3.27 & $(1.07) * * \star$ & 3,838 \\
\hline Never Married, No Children & 0.104 & $(0.021) * * *$ & 4.26 & $(0.92) * \star \star$ & 9,129 \\
\hline
\end{tabular}

Note: Regressions reported above use adjusted SIPP weights and include average predicted earnings over four- to five-year age groups, demographics, and SIPP panel fixed effects. Heteroskedasticity-robust standard errors in parentheses.

*** - Significantly different from zero at the 99 percent confidence level ${ }^{\star \star}$ - 95 percent confidence level * -90 percent confidence level 
Table 6. Regression Results for One Observation Per Year or Month, By Gender, Age, and Family Structure

\begin{tabular}{|c|c|c|c|c|c|}
\hline & \multicolumn{4}{|c|}{ Mean Derivative of $\ln (A \vee G R)$} & \multirow[b]{2}{*}{$\mathrm{N}$} \\
\hline & \multicolumn{2}{|c|}{$\begin{array}{l}\text { Uninsured Ever in Year } \\
\text { (Logit) }\end{array}$} & \multicolumn{2}{|c|}{$\begin{array}{l}\text { Months Uninsured in Year } \\
\text { (Tobit) }\end{array}$} & \\
\hline All & 0.070 & $(0.006) * \star \star$ & 2.78 & $(0.24) * * \star$ & 127,467 \\
\hline Age $18-29$ & 0.124 & 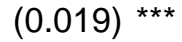 & 2.81 & $(0.45) * \star \star$ & 30,496 \\
\hline Age $30-39$ & 0.074 & $(0.010) * \star \star$ & 3.07 & $(0.40) * \star \star$ & 34,944 \\
\hline Age $40-49$ & 0.065 & $(0.010) * \star \star$ & 3.05 & $(0.47) * * \star$ & 31,551 \\
\hline Age $50-64$ & 0.156 & $(0.004) * \star \star$ & 2.48 & $(0.02) * \star \star$ & 30,373 \\
\hline Never Married & 0.134 & $(0.015) * \star \star$ & 3.04 & $(0.35) * * *$ & 34,903 \\
\hline On First Marriage & 0.049 & $(0.006) * \star \star$ & 2.68 & $(0.34) * * \star$ & 92,498 \\
\hline \multicolumn{6}{|l|}{ Females } \\
\hline All & 0.040 & $(0.006) * \star \star$ & 1.90 & $(0.26) * \star \star$ & 143,700 \\
\hline Age 18-29 & 0.052 & $(0.019) * * \star$ & 1.42 & 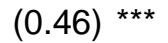 & 33,107 \\
\hline Age $30-39$ & 0.039 & $(0.010) * \star *$ & 1.82 & $(0.43) * \star \star$ & 40,680 \\
\hline Age $40-49$ & 0.046 & $(0.009) * \star \star$ & 2.51 & $(0.48) * * \star$ & 36,641 \\
\hline Age $50-64$ & 0.023 & $(0.009) * * \star$ & 1.86 & $(0.02) * * \star$ & 32,904 \\
\hline Never Married & 0.082 & $(0.014) * \star \star$ & 1.85 & $(0.36) * \star \star$ & 33,725 \\
\hline On First Marriage & 0.027 & $(0.006) * \star \star$ & 1.71 & $(0.34) * \star \star$ & 109,894 \\
\hline Ever Had Children & 0.037 & $(0.007) * * *$ & 1.77 & $(0.30) * * *$ & 102,078 \\
\hline Never Had Children & 0.050 & $(0.011) * * *$ & 2.27 & $(0.44) * \star \star$ & 41,604 \\
\hline Ever Married, Had Children & 0.027 & $(0.006) * \star \star$ & 1.69 & $(0.37) * \star *$ & 91,783 \\
\hline Ever Married, No Children & 0.031 & $(0.012) * \star$ & 2.34 & $(0.86) * * \star$ & 18,093 \\
\hline Never Married, Had Children & 0.105 & $(0.026) * \star *$ & 1.60 & $(0.50) * * *$ & 10,212 \\
\hline Never Married, No Children & 0.076 & $(0.015) * \star \star$ & 2.26 & $(0.48) \star \star \star ~$ & 23,441 \\
\hline
\end{tabular}

\begin{tabular}{|c|c|c|}
\hline Uninsured All Year & $\begin{array}{c}\text { Mean Derivative of } \\
\ln (A \vee G R)\end{array}$ & $\mathrm{N}$ \\
\hline Males & $0.020 \quad(0.004)$ *** & 127,467 \\
\hline Females & $(0.004) * * x$ & 143,633 \\
\hline
\end{tabular}

\begin{tabular}{|c|c|c|c|}
\hline Uninsured in Month & $\begin{array}{r}\text { Mean [ } \\
\ln (\end{array}$ & $\begin{array}{l}\text { vative of } \\
\text { GR) }\end{array}$ & $\mathrm{N}$ \\
\hline Males & 0.051 & 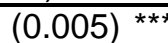 & $1,330,113$ \\
\hline Females & 0.031 & $(0.005) * \star *$ & $1,515,010$ \\
\hline
\end{tabular}

Note: Regressions reported above use adjusted SIPP weights and include average predicted earnings over four- to five-year age groups, demographics, and SIPP panel fixed effects.

Heteroskedasticity-robust, clustered (by individual) standard errors in parentheses.

*** - Significantly different from zero at the 99 percent confidence level ${ }^{* \star}$ - 95 percent confidence level * -90 percent confidence level 
Table 7. Logit Regression Results for Ever Uninsured in Sample on Alternative Volatility Measures, One Observation Per Person

\begin{tabular}{|c|c|c|c|c|c|}
\hline \multirow{2}{*}{ Males } & \multicolumn{4}{|c|}{ Mean Derivative of In(AVGR), where AVGR measures... } & \multirow[b]{2}{*}{$\mathrm{N}$} \\
\hline & \multicolumn{2}{|c|}{$\begin{array}{c}\text { Post-1978 Family Earnings } \\
\text { Volatility }\end{array}$} & \multicolumn{2}{|c|}{$\begin{array}{c}\text { Individual Earnings Volatility, } \\
\text { All Years }\end{array}$} & \\
\hline & & & & & \\
\hline All & 0.08 & $(0.01) * \star *$ & & & 48,907 \\
\hline Age 18-29 & 0.15 & $(0.03) * * *$ & & & 11081 \\
\hline Age $30-39$ & 0.11 & $(0.01) * \star *$ & & & 13281 \\
\hline Age $40-49$ & 0.09 & $(0.01) * * *$ & & & 12071 \\
\hline Age $50-64$ & 0.06 & $(0.01) * * *$ & & & 12402 \\
\hline Never Married & 0.16 & $(0.02) * \star \star$ & 0.155 & $(0.016) * \star \star$ & 13499 \\
\hline On First Marriage & 0.07 & $(0.01) * * *$ & 0.067 & $(0.008) * \star \star$ & 35378 \\
\hline Ever Divorced & & & 0.160 & $(0.021) * * *$ & 6377 \\
\hline \multicolumn{6}{|l|}{ Females } \\
\hline All & 0.06 & $(0.01) * * *$ & & & 55,061 \\
\hline Age 18-29 & 0.06 & $(0.03) * *$ & & & 12002 \\
\hline Age $30-39$ & 0.07 & $(0.01) * * *$ & & & 15498 \\
\hline Age $40-49$ & 0.06 & $(0.01) * \star *$ & & & 14021 \\
\hline Age $50-64$ & 0.05 & $(0.01) * * *$ & & & 13423 \\
\hline Never Married & 0.1 & $(0.02) * \star *$ & 0.102 & $(0.017) * \star \star$ & 12996 \\
\hline On First Marriage & 0.05 & $(0.01) * * *$ & 0.022 & $(0.008) * * \star$ & 42033 \\
\hline Ever Divorced & & & 0.093 & $(0.016) * * *$ & 12889 \\
\hline Ever Had Children & 0.06 & 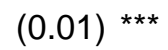 & 0.023 & $(0.008) * \star \star$ & 39013 \\
\hline Never Had Children & 0.08 & $(0.01) * * *$ & 0.067 & $(0.014) * * *$ & 16042 \\
\hline Ever Married, Had Children & 0.05 & $(0.01) * \star *$ & 0.016 & $(0.008)$ * & 35142 \\
\hline Ever Married, No Children & 0.06 & $(0.02) * * *$ & 0.056 & $(0.017) * \star \star$ & 6885 \\
\hline Never Married, Had Children & 0.11 & $(0.03) * * *$ & 0.117 & $(0.026) * * \star$ & 3846 \\
\hline Never Married, No Children & 0.09 & $(0.02) * * *$ & 0.104 & $(0.021) * * *$ & 9129 \\
\hline
\end{tabular}

Note: Regressions reported above use adjusted SIPP weights and include average predicted earnings over four- to five-year age groups, demographics, and SIPP panel fixed effects. Heteroskedasticity-robust standard errors in parentheses.

*** - Significantly different from zero at the 99 percent confidence level ${ }^{* \star}$ - 95 percent confidence level * 90 percent confidence level 